\title{
Clinical listonellosis in meagre (Argyrosomus regius) from recirculated aquaculture system in Turkey
}

\author{
Ezgi Dinçtürk, Tevfik Tansel Tanrıkul \\ Izmir Katip Celebi University, Faculty of Fisheries Department of Aquaculture, Turkey \\ Received December 4, 2017 \\ Accepted June 27, 2018
}

\begin{abstract}
Vibriosis caused by Listonella anguillarum was reported in several fish species from both fresh and saltwater conditions. This pathogen causes disease in rainbow trout, sea bass, and sea bream in Turkey, however, it has not been reported from meagre (Argyrosomus regius) before. Great loss of meagre was observed in the Recirculated Aquaculture System at the Faculty of Fisheries of Izmir Katip Celebi University, which had been transferred from a commercial hatchery for a nutrition experiment. Clinical signs of vibriosis were observed in infected fish, i.e. haemorrhage in the anal area and pectoral fins, mostly as tail ulcers. Petechial haemorrhages in the muscle, liver, peritoneal membranes and pyloric caeca were determined by necropsy. A Gramnegative, rod-shaped, motile bacterium was isolated, showing a positive reaction to oxidase, catalase and gelatin tests, and being sensitive to O/129. Biochemical identification tests and PCR amplifications identified the bacterium as Listonella anguillarum. In slide agglutination test with anti L. anguillarum O1 (ATCC43305) serum, all isolates were positive. The isolated bacteria was resistant to oxytetracycline, sensitive to enrofloxacin, flumequine, phosphomycin, furozulidone, kanamycin and oxolinic acid. In this study, the isolated bacteria from meagre were determined as Listonella anguillarum $\mathrm{O} 1$ with biochemical, moleculer identification and agglutination tests.
\end{abstract}

Listonella anguillarum, fish disease, isolation

Vibriosis that has been found in more than 50 fresh and saltwater fishes is one of the most prevalent fish diseases caused by bacteria belonging to the genus Vibrio. The first known vibriosis outbreak was reported in 1893 in eels as Bacterium anguillarum (Canestrini 1907). In 1909, Bergman proposed the name of Vibrio anguillarum but in 1985, Mac Donell and Colwell reclassified the pathogen into the new genus, Listonella. Currently, both nomenclatures are present in the literature (Hickey and Lee 2017).

Listonellosis, also known as salt-water furunculosis (Rucker 1963), boil disease (Kubota and Takakuwa 1963) and ulcer disease (Bagge and Bagge 1956), is caused by a Gram-negative, polar flagellated, comma-shaped rod bacterium Listonella (Vibrio) anguillarum from the Vibrionaceae family (Actis et al. 1999). It grows on rich media containing $1.5-2.0 \%$ sodium chloride $(\mathrm{NaCl})$ between $25-30^{\circ} \mathrm{C}$ temperatures and forms cream-coloured, round-shaped colonies (Frans et al. 2011). Chemical stress such as water quality, diet composition and pollution, biological stress like population density and the presence of other macro- or micro-organisms, and physical stress due to temperature and overcrowding are important factors that cause outbreaks (Thune et al. 1993; Frans et al. 2011). In addition, the virulence of the $L$. anguillarum strains influences the onset of disease outbreaks (Actis et al. 1999). It has been postulated that in acute epizootics, infected fish dies rapidly without showing any clinical signs (Actis et al. 1999; Toranzo et al. 2005; Austin and Austin 2007; Frans et al. 2011).

In Turkey, L. anguillarum was reported in cultured sea bass (Çăğrgan 1993) and rainbow trout (Oncorhynchus mykiss) (Tanr1kul 2007). Currently, additional isolates were

Address for correspondence:

Ezgi Dinçtürk

Izmir Katip Celebi University

Faculty of Fisheries

Balatçık Mahallesi Havaalanı Șosesi No:33/2

Balatçık 35620 Çiğli İzmir, Turkey

Phone: +90 5396832489

E-mail: ezgi.dincturk@ikc.edu.tr

http://actavet.vfu.cz/ 
described from different fish farms and species as a result of the expanding aquaculture industry. Meagre (Argyrosomus regius) farming started in Turkey in 2007 and now it is one of the alternative species that have increased production numbers because of its favourable biological characteristics such as being resistant to environmental conditions, having good feed conversion, fast growth, and high flesh quality.

The objective of this study was to determine and to identify the biochemical characteristics of Listonella anguillarium serogroup $\mathrm{O} 1$ from meagre. This pathogen has been known for some time but has not been reported previously in Turkey.

Fish

\section{Materials and Methods}

The outbreak was observed in the Recirculated Aquaculture System at Faculty of Fisheries of the Izmir Katip Celebi University. The fish were supplied to the university from a commercial hatchery for a nutrition experiment. The water source of the system was brackish $\left(3.9 \%\right.$ ) water and the temperature was $16 \pm 2{ }^{\circ} \mathrm{C}$ when high mortality was observed.

Bacterial strains

Isolation and identification of bacteria

A total of 25 moribund fish of $20 \mathrm{~g}$ were examined by bacteriological investigations. The isolates from the kidneys of diseased fish were streaked on tryptone soy agar (TSA, Oxoid, UK) including $1.5 \% \mathrm{NaCl}$ and incubated at $21^{\circ} \mathrm{C}$ for $48 \mathrm{~h}$. After primer isolation, the representative colonies were passaged onto thiosulphatecitrate-bile salts-sucrose agar (TCBS, Oxoid, UK). The purified colonies were cultivated on TSA including $1.5 \% \mathrm{NaCl}$ for biochemical tests. Gram staining and oxidase test were carried out according to standard procedures. The motility of the bacteria was detected by the hanging-drop technique. Oxidative and fermentative degradation of glucose and gas production were tested on O/F Medium (Difco, USA). Resistance to the 2,4-diamino-6,7diisopropylpteridine $\mathrm{O} / 129$ vibriostatic agent was tested with discs (Oxoid, UK) on TSA (Oxoid, UK) including $1.5 \% \mathrm{NaCl}$. Biochemical tests for further information were carried out with API 20E (BioMerieux S. A., France) (Tanrikul et al. 2005) which was carried out at $21^{\circ} \mathrm{C}$ for $48 \mathrm{~h}$. Sterile $1.5 \%$ saline was used for inoculation of the bacterium to API 20E strips.

Preparation of antisera and slide agglutination test

Slide agglutination test was performed according to Toranzo et al. (1983). Rabbit serum was used against all isolated L. anguillarım $\mathrm{O} 1$ strains (ATCC 43305). Bacterial growth occurred on brain heart infusion agar (BHIA, Oxoid, UK) plates at $25{ }^{\circ} \mathrm{C}$ for $24-28 \mathrm{~h}$. Bacterial strains were resuspended in PBS (phosphate buffered saline solution) and reached the concentration of McFarland Standard No. 3 for use as antigens in the slide agglutination tests.

Molecular identification of strains

Molecular identification of the bacteria was conducted. The 16S rRNA gene sequence was amplified by polymerase chain reaction (PCR) in order to confirm that the bacteria were Listonella anguillarum. The pathogen was obtained from the samples that were isolated from infected meagre during the outbreak. EurX GeneMATRIX Tissue Bacteria Isolation Kit (EURx Ltd., Poland) was used for DNA isolation. Then with use of Nanodrop 2000 (Thermo Scientific, USA), density and quality of the isolates were determined. The $27 \mathrm{~F}$ and $1492 \mathrm{R}$ primers were used for PCR amplifications. Band screening of the PCR products was observed in the gel electrophoresis. Amplified products of template DNA were sent to the Stab Vida direct sequencing service (Spain) with the ABI 3730 XL DNA Analyzer for sequence determination. Then the sequences were checked against the BLASTN 2.6.1. database.

Antimicrobial sensitivity test

Antibiotic susceptibility of the pathogen was tested with 8 antibiotics on Mueller-Hilton agar (MHA, Merck, Germany) using the Kirby-Bauer disc diffusion technique (Stokes et al. 1993). A loopful of 24 h culture was placed in the center of a Petri dish with media and spread with a dry swab. Test discs of enrofloxacin, florfenicol, flumequine, phosphomycin, furozulidone, kanamycin, oxolinic acid, oxytetracycline and sulphamethoxazole/ trimethoprim (Oxoid, UK) were placed on the dishes and incubated at $21^{\circ} \mathrm{C}$ for $24 \mathrm{~h}$. The disk diffusion zone diameters were measured $(\mathrm{mm})$ and compared with the interpretive criterias of National Commite for Clinical Laboratory Standarts (NCCLS, 1993, 1994).

\section{Results}

The affected meagre exhibited erratic swimming, dark discolouration, haemorrhage in the anal area and pectoral fins, and tail ulcers as clinical signs. High mortality was observed 
and calculated as $30 \%$ during the outbreak. Necropsy showed petechial haemorrhage in the muscle, liver, peritoneal membranes and pyloric caeca from the internal sides of the fish (Plate VIII, Fig. 1).

The morphologic and biochemical properties of isolated L. anguillarum $\mathrm{O} 1$ are presented in Table 1. The isolates were found to be Gram-

Table 1. The morphologic and biochemical properties of isolated Listonella anguillarum

\begin{tabular}{|c|c|}
\hline Properties & L. anguillarum $\mathrm{O} 1$ strains \\
\hline Gram stain & $-(12 / 12)$ \\
\hline Motility & $+(12 / 12)$ \\
\hline Oxidase & $+(12 / 12)$ \\
\hline Catalase & $+(12 / 12)$ \\
\hline $\mathrm{O} / \mathrm{F}$ & $\mathrm{F}(12 / 12)$ \\
\hline $\mathrm{O} / 129$ & $+(12 / 12)$ \\
\hline ONPG & $+(12 / 12)$ \\
\hline $\mathrm{ADH}$ & $+(12 / 12)$ \\
\hline LDC & $-(12 / 12)$ \\
\hline ODC & $-(12 / 12)$ \\
\hline Citrate utilization & $+(12 / 12)$ \\
\hline $\mathrm{H}_{2} \mathrm{~S}$ & $-(12 / 12)$ \\
\hline Urease & $-(12 / 12)$ \\
\hline TDA & $-(12 / 12)$ \\
\hline Indole & $-(12 / 12)$ \\
\hline VP & $+(12 / 12)$ \\
\hline Gelatin & $+(12 / 12)$ \\
\hline Glucose & $+(12 / 12)$ \\
\hline Mannitol & $+(12 / 12)$ \\
\hline Inositol & $+(12 / 12)$ \\
\hline Sorbitol & $+(12 / 12)$ \\
\hline Rhamnose & $-(12 / 12)$ \\
\hline Sucrose & $+(12 / 12)$ \\
\hline Melibiose & $-(12 / 12)$ \\
\hline Amygdalin & $-(12 / 12)$ \\
\hline Arabinose & $+(12 / 12)$ \\
\hline
\end{tabular}

+ positive; - negative

$\mathrm{O} / \mathrm{F}$ (Oxidative-fermentative medium),

O/129 (2,4-diamino-6,7-diisopropylpteridine),

ONPG (ortho-nitrophenyl- $\beta$-galactoside),

$\mathrm{ADH}$ (arginine dihydrolase),

LDC (lysine decarboxylase),

ODC (ornithine decarboxylase),

$\mathrm{H}_{2} \mathrm{~S}$ ( $\mathrm{H}_{2} \mathrm{~S}$ production),

TDA (deaminase), VP (acetoin production) negative, motile, oxidase and catalase positive. According to API 20E rapid identification tests, ONPG (ortho-nitro-phenyl-galactoside), ADH (arginine dihydrolase), citrate utilization, VP (Voges Proskauer test), gelatin degradation, acid production from glucose, mannitol, inositol, sorbitol, arabinose and sucrose were found positive; LDH (lysine decarboxylase), ODC (ornithine decarboxylase), $\mathrm{H}_{2} \mathrm{~S}$, urease, TDA (tryptophan deaminase), indole, rhamnose, melibiose and amygdalin were detected negative in all isolates from diseased fish. In slide agglutination test with anti L. anguillarum O1 (ATCC43305) serum, showed that all 12 isolates were positive. No other pathogen was detected from the diseased fish.

The PCR amplification of the L. anguillarum gene sequence was registered in the BLASTN 2.6.1 database. It resulted in $100 \%$ nucleotide identity between the current isolate and Listonella anguillarum (accession number CP023208.1).

The antibiotic susceptibility results of isolated L. anguillarum $\mathrm{O} 1$ strains are presented in Table 2. The pathogen showed resistance to oxytetracycline and it was susceptible to enrofloxacin, flumequine, phosphomycin, furozulidone, kanamycin and oxolinic acid. The intermediate intensity of antibiotics were detected in florfenicol and sulphamethoxazole/trimethoprim test groups.

Infected fish were treated with enrofloxacin added to dry pellet feed $\left(50 \mathrm{mg} \cdot \mathrm{kg}^{-1}\right.$ fish per day) for 7 consecutive days with $1.3 \%$ feed ratio.

\section{Discussion}

Listonella (Vibrio) anguillarum is a worldwide known bacterial pathogen causing typical haemorrhagic septicaemia in a great variety of fish species (Powell et al. 1990; Rad and Shahsanavi 2010). When fish are under stress due to overcrowding or when immunocompromised, outbreaks are usually observed caused by vibrio strains (Thune et al. 1993). Major changes in the water salinity and stress made meagre more vulnerable to fish pathogens in this vibriosis outbreak. Erratic swimming, haemorrhage in the anal and pectoral fins, dark discolouration, petechial haemorrhage in the muscle, liver, pyloric caeca, and peritoneal membranes were observed as typical clinical signs (Demircan and Candan 2006; Tanrıkul 2007). 
Table 2. Antibiotic susceptibility profile of the isolated Listonella anguillarum O1 strains.

\begin{tabular}{|c|c|c|c|}
\hline Antibiotic $(\mu \mathrm{g} / \mathrm{disc})$ & Isolate (12/12) & Antibiotic $(\mu \mathrm{g} /$ disc $)$ & Isolate $(12 / 12)$ \\
\hline Enrofloxacin (5) & $\mathrm{S}(37 \mathrm{~mm})$ & Kanamycin (30) & $\mathrm{S}(22 \mathrm{~mm})$ \\
\hline Florfenicol (30) & $\mathrm{I}(15 \mathrm{~mm})$ & Oxolinic acid (30) & $\mathrm{S}(33 \mathrm{~mm})$ \\
\hline Flumequine (30) & $\mathrm{S}(42 \mathrm{~mm})$ & Oxytetracycline (30) & $\mathrm{R}(2 \mathrm{~mm})$ \\
\hline Fosfomycin (50) & $\mathrm{S}(46 \mathrm{~mm})$ & Sulphamethoxazole / & \\
\hline Furozulidone (50) & $\mathrm{S}(39 \mathrm{~mm})$ & Trimethoprim (25) & $\mathrm{I}(14 \mathrm{~mm})$ \\
\hline
\end{tabular}

S: sensitive; R: resistant, I: intermediate

Vibrio disease was reported by Rucker in 1954 and since then it has appeared in different fish species such as yellowtail (Seriola quinqueradiata) (Jo et al. 1979), ayu (Plecoglossus altivelis) (Muroga and Egusa 1967), turbot (Scophthalmus maximus) (Horne et al. 1977), striped bass (Morone saxatilis) (Toranzo et al. 1983), cod (Gadus morhua) (Egidius and Andersen 1984), red sea-bream (Pagrus major) (Muroga and Tatani 1982), European eel (Anguilla anguilla) (Rodsaether et al. 1977), Japanese eel (Anguilla japonica) (Kitao et al. 1983), gilthead sea-bream (Sparus aurata) (Paperna et al. 1977), and tilapia (Oreochromis auretus) (Tareen 1984). In meagre (Argyrosomus regius) Haenen et al. (2014) reported $V$. anguillarum serotype $\mathrm{O} 1$ from offshore cages. In Turkey vibriosis has occurred at mariculture facilities for a long time. Especially $V$. anguillarum $\mathrm{O} 1$ was isolated from sea bream, sea bass and rainbow trout farms (Çăgırgan 1993; Tanrıkul et al. 2005; Korun and Timur 2008).

Meagre was indicated as fast-growing, fairly fecund and longlived but it has been reported that the biology, ecology and fisheries of this species are poorly documented, especially in European waters (Quéméner 2002; Prista 2013). In recent years it has been considered as a potential candidate for culture in Turkey. Diseases caused by L. anguillarum were detected in both hatcheries and cages with increasing production rates. Juveniles were destroyed and adult individuals were treated with antibiotics without determining the pathogen to fight the disease. The disease has been known in hatchery and cage culture of meagre in Turkey but has not been reported before. Therefore, this study is the first declaration of Listonella anguillarum $\mathrm{O} 1$ from Argyrosomus regius in Turkey.

Phenotypic characteristics like Gram staining, motility, oxidase and catalase reactions of L. anguillarum strains were detected in accordance with Austin and Austin (2007). The API 20E rapid identification systems have been used for L. anguillarum strains (Tanrikul et al. 2005; Tanrikul 2007). According to the API 20E results the isolate was identified as L. anguillarum and no biochemical differences were detected on the isolated L.anguillarum strains. These findings are similar to Tanrikul et al (2005), Demircan and Candan (2006), Korun (2006) and Avsever (2014) for different marine species, mostly sea bass (Dicentrarchus labrax) as well as isolations from rainbow trout (Tanrikul 2007; Tanrikul and Gultepe 2011). Some indicators such as ADH, indole, inositol, sorbitol and arabinose vary among different studies (Table 3), but biochemical results are not the essential criteria to identify the bacteria. The results of biochemical studies showed that biochemical properties in different species do not vary with the salinity of water (Table 3 ).

The sensitivity of $L$. anguillarum strains to chemotherapeutics has been decreasing so far (Takahashi et al. 1976). In antimicrobial susceptibility tests, resistance to oxytetracycline was detected in the bacteria. Tanrikul (2007) reported that some L. anguillarum strains isolated from rainbow trout showed resistance to enrofloxacin and oxytetracycline. On the contrary, the strains isolated from aquarium catfish were determined sensitive to enrofloxacin and oxytetracycline, but resistant to penicillin ( $\mathrm{Rad}$ and Shahsavani 2010). 
Table 3. The morphologic and biochemical test results of Listonella anguillarum from different studies.

\begin{tabular}{|c|c|c|c|c|c|c|c|}
\hline & $\begin{array}{c}\text { Isolated } L \text {. } \\
\text { anguillarum } \\
(12 / 12)\end{array}$ & $\begin{array}{c}\text { Tanrikul } \\
\text { et al. } \\
2004\end{array}$ & $\begin{array}{c}\text { Demircan and } \\
\text { Candan } \\
2006\end{array}$ & $\begin{array}{l}\text { Korun } \\
2006\end{array}$ & $\begin{array}{c}\text { Avsever } \\
2014\end{array}$ & $\begin{array}{c}\text { Tanrikul } \\
2007\end{array}$ & $\begin{array}{c}\text { Tanrikul and } \\
\text { Gultepe } \\
2011\end{array}$ \\
\hline Gram stain & - & - & - & - & - & - & - \\
\hline Motility & + & + & + & + & + & + & + \\
\hline Catalaze & + & + & + & + & + & + & + \\
\hline Oxidase & + & + & + & + & + & + & + \\
\hline Growth in $0 \% \mathrm{NaCl}$ & ND & $+/-$ & ND & - & - & - & - \\
\hline Growth in $7 \% \mathrm{NaCl}$ & ND & $+/-$ & + & - & + & - & - \\
\hline Sensivity to $\mathrm{O} / 129$ & + & + & + & + & + & + & + \\
\hline $\mathrm{O} / \mathrm{F}$ & $\mathrm{F}$ & ND & $\mathrm{F}$ & $\mathrm{F}$ & $\mathrm{F}$ & $\mathrm{F}$ & $\mathrm{F}$ \\
\hline ONPG & + & + & + & + & + & + & + \\
\hline $\mathrm{ADH}$ & + & + & + & + & - & + & + \\
\hline $\mathrm{LDH}$ & - & - & - & - & - & - & - \\
\hline ODC & - & - & - & - & - & - & - \\
\hline Citrate utilization & + & $+/-$ & + & ND & ND & + & + \\
\hline $\mathrm{H}_{2} \mathrm{~S}$ & - & - & - & - & - & - & - \\
\hline Urease & - & - & - & - & - & - & - \\
\hline TDA & - & - & - & ND & ND & - & - \\
\hline Indole & - & $+/-$ & + & + & + & - & - \\
\hline VP & + & + & + & + & + & + & + \\
\hline Gelatin & + & + & + & + & + & + & + \\
\hline Glucose & + & + & + & + & + & + & + \\
\hline Mannitol & + & + & + & + & + & + & + \\
\hline Inositol & + & $+/-$ & - & - & - & + & + \\
\hline Sorbitol & + & $+/-$ & + & + & - & + & + \\
\hline Rhamnose & - & - & - & - & + & - & - \\
\hline Sucrose & + & + & + & + & - & + & + \\
\hline Melibiose & - & - & - & - & + & - & - \\
\hline Amygladin & - & - & - & - & ND & - & - \\
\hline Arabinose & + & - & + & - & + & + & + \\
\hline
\end{tabular}

+ positive; - negative

O/F (Oxidative-fermentative medium), O/129 (2,4-diamino-6,7-diisopropylpteridine),

ONPG (ortho-nitrophenyl- $\beta$-galactoside), ADH (arginine dihydrolase), LDC (lysine decarboxylase), ODC (ornithine decarboxylase), $\mathrm{H}_{2} \mathrm{~S}$ ( $\mathrm{H}_{2} \mathrm{~S}$ production), TDA (deaminase), VP (acetoin production),

ND (not done)

These results showed that antimicrobial susceptibility may vary depending on the strain. In addition, L. anguillarum which is a fish pathogen is not included in the EUCAST list, so these results could not be compared with their criteria but the zone diameters were resulted according to the NCCLS criteria..

In conclusion, there is not sufficient information about meagre infected with L.anguillarum in literature. It was not reported in Turkey before and limited information is reported from different countries. Haenen et al. (2014) mentioned this pathogen in different species including meagre in their review but this is the first scientific research about the microbiology and identification of this pathogen from meagre. There is limited information regarding diseases in this fish species and the findings of our study may contribute to meagre health management. 


\section{References}

Actis LA, Tolmasky ME, Crosa JH 1999: Vibriosis. In Woo PTK, Bruno DW (Eds): Fish Diseases and Disorders: Viral, Bacterial and Fungal Infections, Vol. 3, CABI International, Wallingford, UK, pp 523-558

Austin B, Austin DA 2007: Bacterial Fish Pathogens: Diseases of Farmed and Wild Fish, $4^{\text {th }}$ edn. Springer-Praxis Publishing, New York-Chichester

Avsever ML 2014: Investigation of the pathogenicity status of the Listonella anguillarum (Vibrio anguillarum) isolates from marine fish cultured in the Aegean Region with multiplex PCR. Ege University Institute of Science, $\mathrm{PhD}$ thesis

Bagge J, Bagge O 1956: Vibrio anguillarum som arsagtilulcussygdom has torsk (Gadus callarias L.) (Vibrio anguillarum as cause of the ulcer disease in cod). Nord Vet Med 8: 481-492.

Canestrini G 1907: La malattia dominante delle anguille. Atti Institute Veneto Service, Italy, pp 809-814

Çağırgan H 1993: An investigation on the diagnosis and treatment of cultured sea bass and sea bream. Ph.D. Thesis, Ege University, Faculty of Fisheries, Turkey.

Demircan D, Candan A 2006: Identification of Vibrio anguillarum by PCR (rpoN gene) associated with vibriosis in marine fish in Turkey. Turk J Vet Anim Sci 30: 305-310

Egidius E, Andersen K 1984: Disease problems in cod rearing. In Ddhl E, Danielsen D, Moksness E, Solemdal P (eds): The propagation of cod Gadus morhua, L. vol. 1. Flodevigen Rapp., Bergen, pp 761-772

Frans I, Michiels CW, Bossier P, Willems KA, Lievens B, Rediers H 2011: Vibrio anguillarum as a fish pathogen: virulence factors, diagnosis and prevention. J Fish Dis 34: 643-661

Haenen OLM, Fouz B, Amaro C, Isern MM, Zrncic S, Travers MA, Renault T, Wardle R, Hellström A, Dalsgaard I 2014: Vibriosis in aquaculture. 16th EAFP Conference, Tampere, Finland, 4th September 2013: workshop report. Bulletin of the European Association of Fish Pathologists, 34: 138

Hickey ME, Lee JL 2017: A comprehensive review of Vibrio (Listonella) anguillarum: ecology, pathology and prevention. Reviews in Aquaculture doi:10.1111/raq.12188

Horne MT, Richards RH, Roberts RJ, Smith PC 1977: Peracute vibriosis in juvenile turbot Scophthalmus maximus. J Fish Biol 11: 355-361

Jo Y, Ohnishi K, Muroga K 1979: Vibrio anguillarum isolated from cultured yellowtail. Fish Pathol 14: 43-47

Kitao T, Aoki T, Fukudome M, Kawano K, Wada Y, Mizuno Y 1983: Serotyping of Vibrio anguillarum from diseased freshwater fish in Japan. J Fish Dis 6: 175-181

Korun J 2006: A study on Listonella anguillarum infection found in cultured gilt-head sea bream (Sparus aurata L.) (in Turkish). EgeJFAS 23: 2

Korun J, Timur G 2008: Marine vibrios associated with diseased sea bass (Dicentrarchus labrax) in Turkey. J FisheriesSciences.com 2: 66-76

Kubota SS, Takakuwa M 1963: Studies on the disease of marine culture fishes. $1^{\text {st }}$ general description and preliminary discussion of fish diseases at Mie prefecture. Journal of the Faculty of Fisheries of the Prefectural University of Mie 6: 107-124

Muroga K, Egusa S 1967: Vibrio anguillarum from an endemic disease of ayu in Lake Hamana. Bull Japan Soc Sci Fish 33: 636-640

Muroga K, Tatani M 1982: Isolation of Vibrio anguillarum from juvenile red sea-bream (Pagrus major). Fish Pathol 16: 211-214

NCCLS 1993: Performance Standards for Antimicrobial Disk Susceptibility Tests. $5^{\text {th }}$ Edition, Approved Standard, M2-A5, 13, 24, Villanova, PA

NCCLS 1994: Performance Standards for Antimicrobial Disk Susceptibility Tests. $5^{\text {th }}$ Informational Supplement, M100-S5, 14, 16, Villanova, PA

Paperna I, Colorni A, Gordin H, Kissel GW 1977: Diseases of Sparus aurata in marine culture at Ellat. Aquaculture 10: 195-213

Powell JL, Loutit MW 1990: Isolation and characterization of Vibrio anguillarum from selected marine sites in New Zealand. New Zeal J Mar Fresh 24: 267-273

Prista NMGG 2013: Argyrosomus regius (Asso, 1801) fishery and ecology in Portuguese waters, with reference to its relationships to other European and African populations. Doutoramento em Biologia Especialidade Biologia Marinha e Aquacultura, Universidade de Lisboa, Faculdade de Ciências Departamento de Biologia Animal, 2013.

Quéméner L 2002: Le maigre commun (Argyrosomus regius): Biologie, pêche, marché etpotentiel aquacole. Ifremer, Plouzané, France

Rad M, Shahsavani D 2010: Isolation and characterization of Vibrio (Listonella) anguillarum from catfish. Turk J Vet Anim Sci 34: 413-415

Rodseather MC, Olafsen J, Raa J, Myhre K, Steen JB 1977: Copper as an initiating factor of vibriosis (Vibrio anguillarum) in eel (Angullla anguilla) J Fish Biol 10: 17-21

Rucker RR 1963: Status of Fish Diseases and Relation to Production. Report of The Second Governors Conference on Pacific Salmon, Seattle, pp. 98-110 
Stokes EJ, Ridgway GL, Wren MDV 1993: laboratory control of antimicrobial chemotherapy. In Stokes EJ (Ed.): Clinical Microbiology. $7^{\text {th }}$ edn., Edward Arnoid, London, pp: 234-280

Takahashi T, Inove S, Hiramoto K, Miyazawa K 1976: Amounts of indestion and concentrations in tissue resulting from oral administration in Engraulis japonica of sulfamonomethoxine. Fish Pathol 11: 1-4

Tanrikul TT 2007: Vibriosis as an epizootic disease of rainbow trout (Onchorynchus mykiss) in Turkey. PJBS 10: $1733-1737$

Tanrıkul TT, Çağırgan H, Tokşen E 2005: The use of API 20E fort he identification of isolated Vibrio sp. from cultured sea bass (Dicentrarchus labrax L.). Turk J Vet Anim Sci 20: 483-490

Tanrıkul TT, Gültepe N 2011: Mix infections in rainbow trout (Oncorhynchus mykiss Walbaum): Lactococcus garvieae and Vibrio anguillarum O1. J Anim Vet Adv 10: 1019-1023

Tareen IU 1984: Vibriosis in Oreochromis aureus acclimatized to seawater: control and prophylaxis. EAFP 4: 47-49

Thune RL, Stanley LA, Cooper K 1993: Pathogenesis of Gram-negative bacterial infections in warm water fish. Annu Rev Fish Dis 3: 37-68

Toranzo AE, Barja JL, Potter SA, Colwell RR, Hetrick FM, Crosa JH 1983: Molecular factors associated with virulence of marine vibrios isolated from the striped bass in the Chesapeake Bay. Infect Immun 39: 1220-1227

Toranzo AE, Magarinos B, Romalde JL 2005: A review of the main bacterial fish diseases in mariculture systems. Aquaculture 246: 37-61 
Plate VIII

Dinçtürk E. et al.: Clinical listonellosis ... pp. 269-275

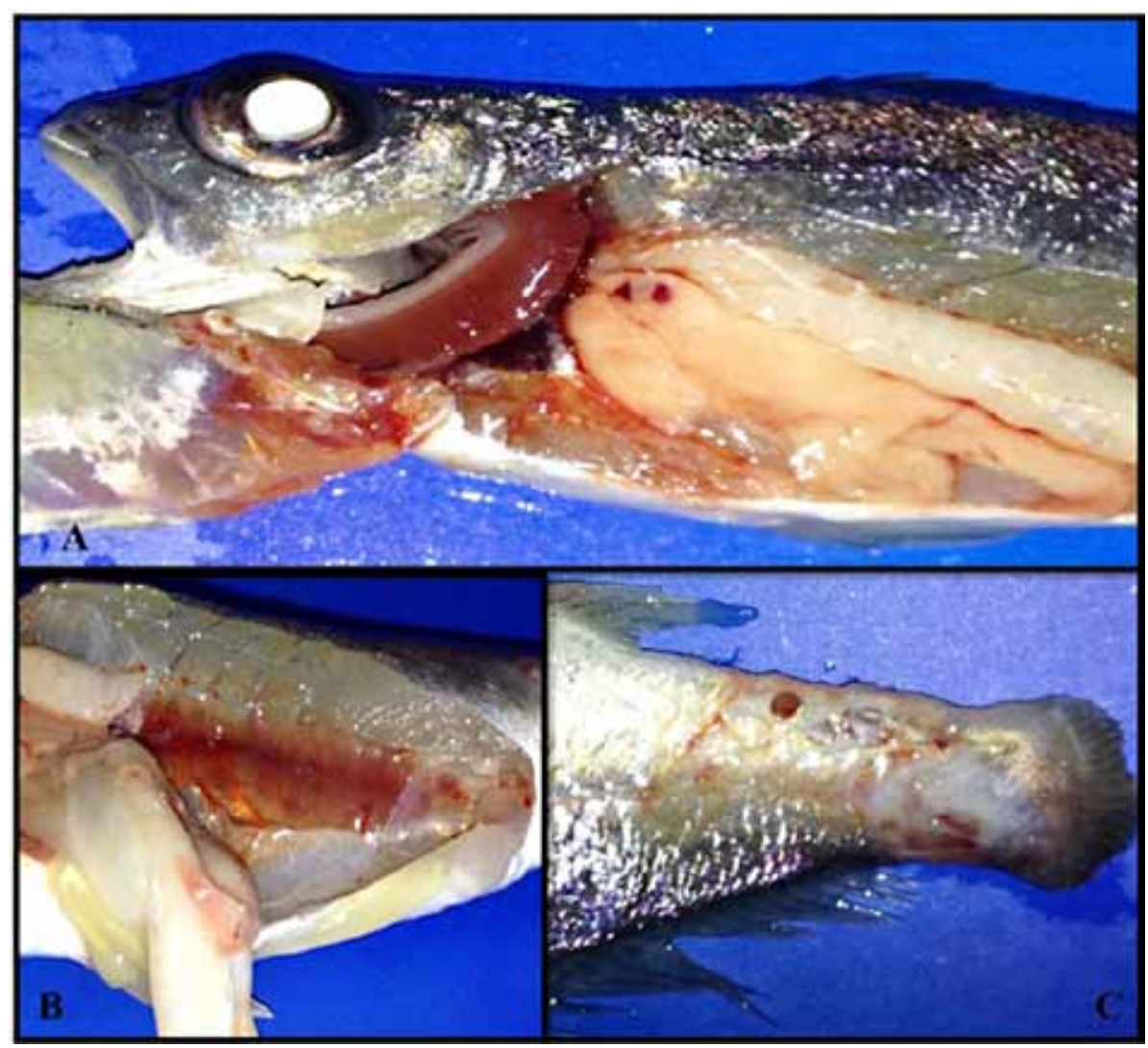

Fig. 1.A: Petechial haemorrhage in the liver; B: haemorrhage in the kidneys; C: tail ulcer 